\title{
Total Cholesterol Level of Hypercholesterolemia Male Wistar Rats (Rattus norvegicus) with Ethanol Extracts of Purple Sweet Potato Leaf (Ipomoea batatas (L.) Lam)
}

\section{Kadar Kolesterol Total Tikus Hiperkolesterolemia dengan Pemberian Ekstrak Etanol Daun Ubi Jalar Ungu (Ipomoea batatas (L.) Lam)}

Siti Fatimah*, Desto Arisandi, Meirina Sindi Saputri

\begin{abstract}
The increase in total cholesterol level increases the risk of cardiovascular disease. Sweet potato leaves are a food that contains polyphenols, flavonoids, quercetin, tannin, and fiber that effectively lower total cholesterol levels. This study aims to analyze the effect of ethanol extracts of leaf purple sweet potato on serum total cholesterol levels of rats fed a high-fat diet. An experimental study with design pre and posttest carried out on 10 male Wistar rats (Rattus norvegicus) fed a high-fat, which are 2 groups: 1 group the control hypercholesterolemia and 1 group ethanol extracts of leaf purple sweet potato. Dose based on leaves of quercetin that is equal to $2 \mathrm{mg} / \mathrm{kgBB}$. The average content of quercetin ethanol extracts of leaf purple sweet potato was analyzed to obtain $14,08 \mathrm{mg} / 100 \mathrm{~g}$. Ethanol extracts of leaf purple sweet potato are given for 14 days by way of on the sonde. Serum total cholesterol was determined by the CHOD-PAP method. The data obtained were analyzed descriptively. The result of this study obtained the average total cholesterol level of white blood rats before giving ethanol extracts of leaf purple sweet potato that is $189,89 \mathrm{mg} / \mathrm{dl}$, whereas after administration of ethanol extracts of leaf purple sweet potato dose $2 \mathrm{mg} / \mathrm{kgBB}$ that is $131,92 \mathrm{mg} / \mathrm{dl}$. The decrease in total cholesterol level of white rats after giving ethanol extracts of leaf purple sweet potato with dose $2 \mathrm{mg} / \mathrm{kgBB}$ that is 30,52 $\%$.
\end{abstract}

Keyword: Total cholesterol, extracts, Purple Sweet Potato Leaf

Afiliasi Penulis

STIKes Guna Bangsa Yogyakarta

Korespondensi kepada

S. Fatimah

siti_fatimah@gunabangsa.ac.id 


\section{Intisari}

Peningkatan kadar kolesterol total meningkatkan resiko terjadinya penyakit kardiovaskuler. Daun ubi jalar merupakan bahan makanan yang mengandung polifenol, flavonoid, quercetin, tannin, dan serat yang efektif menurunkan kadar kolesterol total. Penelitian ini bertujuan untuk mengetahui kadar kolesterol total pada tikus hiperkolesterolemia sebelum dan sesudah pemberian ekstrak etanol daun ubi jalar ungu (Ipomoea batatas (L.) Lam). Jenis penelitian ini adalah penelitian exsperimental dengan rancangan pretest and posttest dilakukan pada tikus wistar jantan (Rattus norvegicus) yang diperi pakan tinggi lemak yang dikelompokkan menjadi 2 kelompok yaitu: 1 kelompok kontrol hiperkolesterolemia dan 1 kelompok yang diberikan ekstrak etanol daun ubi jalar ungu. Dosis berdasarkan kadar quercetin yaitu sebesar $2 \mathrm{mg} / \mathrm{kgBB}$. Kadar rata-rata quercetin ekstrak etanol daun ubi jalar ungu dianalisis sehingga diperoleh 14,08 mg/100g. Ekstrak etanol daun ubi jalar ungu diberikan selama 14 hari dengan cara sonde. Kadar kolesterol total serum ditentukan melalui metode CHOD-PAP. Data yang diperoleh dianalisis secara deskriptif.Hasil penelitian ini didapat rerata kadar kolesterol total darah tikus putih sebelum pemberian ekstrak etanol daun ubi jalar ungu yaitu 189,89 mg/dl, sedangkan setelah pemberian ekstrak etanol daun ubi jalar ungu dosis $2 \mathrm{mg} / \mathrm{kgBB}$ yaitu 131,92 mg/dl.Penurunan kadar kolesterol total darah tikus putih sesudah pemberian ekstrak etanol daun ubi jalar ungu dengan dosis 2 $\mathrm{mg} / \mathrm{kgBB}$ yaitu $30,52 \%$

Kata kunci: Kolesterol total, ekstrak, daun ubi jalar ungu

\section{Pendahuluan}

\begin{tabular}{cccc}
\hline Lemak dianggap & berbahaya & bagi \\
kesehatan setelah adanya & penelitian yang
\end{tabular}
menunjukkan hubungan antara kematian dengan bertambahnya jumlah penderita penyakit jantung koroner (PJK). Mengkonsumsi lemak secara berlebihan tidak terlepas dari pergeseran pola hidup, terutama pola makanan masyarakat. Masyarakat di negara maju sudah mulai mmenyadari pentingnya mengurangi kadar lemak dan kolesterol yang dapat membahayakan kesehatan tetapi berbanding terbalik dengan negara berkembang dimana banyaknya makanan cepat saji yang tidak mengandung banyak zat berguna untuk tubuh menyebabkan kesehatan tubuh menurun [1]. Risiko tinggi untuk mendapatkan PJK sangat erat berhubungan dengan kadar kolesterol yang tinggi, terlebih komplikasi dasar seperti hipertensi (tekanan darah tinggi) dan obesitas (kegemukan). Tubuh mengalami mekanisme yang lebih banyak di dinding pembuluh darah. Kolesterol bisa menempel pada dinding pembuluh darah sehingga menyebabkan penyempitan [2].

Masyarakat dunia sekarang ini semakin banyak memilih menggunakan obat herbal untuk mengatasi masalah kesehatan. Obat herbal dinilai lebih aman daripada obat sintetik (modern), selain harga obat sintetik lebih mahal risiko terjadinya efek samping juga semakin besar. Penggunaan obat herbal bukan berarti aman tanpa efek samping, namun jika penggunaan obat herbal tidak tepat maka tidak memberikan daya guna yang baik bahkan dapat menimbulkan efek samping yang tidak diinginkan.

Salah satu tanaman yang digunakan sebagai obat anti kolesterol adalah daun ubi jalar ungu (Ipomoea batatas (L.)Lam). Tanaman daun ubi jalar ungu mempunyai kandungan gizi yang cukup melimpah, antara lain karbohidrat, protein, vitamin, $\beta$-karoten, dan pigmen antosianin yang dibutuhkan oleh tubuh. Manfaat lainnya juga sebagai sumber antioksidan yang dapat berperan melawan radikal bebas [3]. Berdasarkan hasil penelitian [4], bahwa ekstrak (EtOH; $\mathrm{HCl}$ ) daun ubi jalar ungu positif mengandung komponen metabolit sekunder golongan flavonoid dan tanin serta memiliki aktivitas antioksidan yang relatif lebih tinggi berbanding dengan alfa tokoferol yang merupakan senyawa populer antioksidan. Adanya kandungan antioksidan yang lebih tinggi pada ekstrak $(\mathrm{EtOH} ; \mathrm{HCl})$ daun ubi jalar ungu, membuat peneliti tertarik untuk melakukan penelitian 
tentang kadar kolesterol total tikus hiperkolesterolemia dengan pemberian ekstrak etanol daun ubi jalar ungu (Ipomoea batatas (L.) Lam). Penelitian ini diharapkan memberikan gambaran mengenai potensi ekstrak etanol daun ubi jalar ungu (Ipomoea batatas (L.) Lam) sebagai antihiperkolesterolemia.

\section{Metode}

Alat

Alat yang digunakan adalah kandang hewan coba, timbangan analitik, oven, waterbath, sentrifuge, chamber, spektrofotometer UV-Vis, spuit $3 \mathrm{ml}$, kuvet, sentrifuge, tabung mikrohematokrit, yellow tip, blue tip, mikropipet, cup serum, sampel serum, etanol $70 \%$, reagen standar kolesterol.

\section{Bahan}

Bahan yang digunakan adalah tikus putih (Rattus novergicus), etanol $70 \%$, silica gel F245, etil asetat, methanol, asam formiat, sampel serum, reagen standar kolesterol.

\section{Prosedur penelitian}

\section{Persiapan hewan percobaan}

Sebanyak 10 ekor tikus putih (Rattus novergicus) terlebih dahulu diadaptasi dengan lingkungan tempat penelitian selama 3 hari dengan diberi makan standar yang cukup. Sebanyak 5 ekor tikus putih sebagai kelompok kontrol dengan kolesterol total tinggi, dan 5 ekor tikus putih sebagai kelompok perlakuan.

\section{Pembuatan ekstrak etanol daun ubi jalar ungu} (Ipomoea batatas (L.) Lam)

Daun ubi jalar ungu segar disortasi terlebih dahulu, kemudian dicuci pada air mengalir lalu dikering-anginkan. Daun ubi jalar ungu selanjutnya ditimbang sebanyak 2 kg. Daun ubi jalar ungu kemudian dikeringkan menggunakan oven dengan suhu $50^{\circ} \mathrm{C}$. Daun ubi jalar ungu yang telah kering lalu dihaluskan menggunakan mesin giling kering. Proses tersebut diperoleh hasil berupa serbuk (simplisia). Simplisia kemudian dimaserasi dengan etanol $70 \%$ selama 24 jam sambil diaduk 3 jam sekali. Bahan kemudiandisaring menggunakan kain kasa lalu diendapkan, selanjutnya diuapkan menggunakan waterbath pada suhu $70^{\circ} \mathrm{C}$ dengan bantuan kipas angin
Penetapan kadar quercetin pada ekstrak daun ubi jalar ungu (Ipomoea batatas (L.) Lam)

Sampel $100 \mathrm{mg}$ ditimbang terlebih dahulu secara seksama, kemudian diekstraksi dengan etanol sebanyak $5 \mathrm{ml}$, dihomogenkan dan dimaserasi selama 24 jam. Supernatan diambil dan residu diekstraksi ulang dengan etanol $2 \mathrm{ml}$. Supernatan dievaporasikan dengan menggunakan gas nitrogen di atas penangas air, kemudian ditambahkan ethanol 0,5 $\mathrm{ml}$ dan dilarutkan dengan menggunakan sonikasi selama 15 menit. Larutan selanjutnya disentrifuge selama 5 menit. Supernatan dispoting sebanyak $20 \mu \mathrm{l}$ pada plate silica gel F245, kemudian dimasukkan ke dalam chamber jenuh fase gerak etil asetat:methanol: asam formiat (95:5:1), elusi hingga batas atas plat, kemudian plat diangkat dan dikeringkan. Plat didensito pada panjang gelombang $341 \mathrm{~nm}$.

Pengujian pemberian ekstrak etanol daun ubi jalar ungu (Ipomoea batatas (L.) Lam) terhadap penurunan kadar kolesterol total

Masing-masing kelompok terdiri dari 5 ekor tikus putih (Rattus norvegicus). Tikus putih di adaptasi selama 3 hari dan berat badan tikus ditimbang. Tikus putih diberi pakan tinggi lemak selama 7 hari, kemudian berat badan tikus ditimbang dan dilakukan pengambilan darah untuk mengetahui kadar kolesterol total (pre test). Langkah selanjutnya diberi ekstrak daun ubi jalar ungu selama 14 hari. Tikus dipuasakan dan kemudian dilakukan pengambilan darah untuk mengetahui kadar kolesterol total. Kelompok I sebagai kontrol tikus putih hiperkolesteolemia. Kelompok II yaitu tikus putih hiperkolesterolemia yang diberi ekstrak etanol daun ubi jalar ungu. Penentuan dosis ekstrak etanol daun ubi jalar ungu berdasarkan kadar quercetin yaitu sebesar 2 $\mathrm{mg} / \mathrm{kgBB} /$ hari.

\section{Pengambilan spesimen darah}

Spesimen darah diambil pada vena tikus putih melalui sinus orbitalis dengan menggunakan mikro hematokrit. Darah yang keluar dari tabung mikro hematokrit ditampung pada cup serum. Darah kemudian didiamkan selama 15 menit lalu disentrifugasi dengan kecepatan 3000 rpm, maka akan didapatkan serum untuk diperiksa kadar kolesterol total dengan menggunakan metode 
CHOD-PAP menggunakan spektrofotometer pada panjang gelombang $546 \mathrm{~nm}$.

\section{Pemeriksaan kadar kolesterol total}

Alat dan bahan disiapkan, Pipet ke dalam kuvet seperti pada tabel 1

Reagen dicampur, kemudian diinkubasi selama 10 menit pada $37^{\circ} \mathrm{C}$. Absorbansi pemeriksaan dan standar dibaca terhadap blanko pada panjang gelombang $546 \mathrm{~nm}$. Pembacaan absorbansi tidak lebih dari 60 menit. Perhitungan kadar kolesterol total darah dengan metode CHOD-PAP yaitu:

Kadar kolesterol total = absorbansi sampel/ absorbansi standar $\mathrm{X}$ konsentrasi standar (200 $\mathrm{mg} / \mathrm{dl}$ )

\section{Analisis Data}

Data pemeriksaan kadar kolesterol total yang dikumpulkan diolah menggunakan Statistical Packages for the Social Sciences (SPSS) 17,0 dan program Microsoft excel 2007 dan dianalisis secara deskriptif dengan mencari nilai rata-rata dalam bentuk tabel, dan narasi.

\section{Hasil \& Pembahasan}

Penelitian ini menggunakan 10 hewan coba yang terdiri dari 5 ekor kelompok hewan uji yang digunakan dalam penelitian ini adalah tikus putih (Rattus norvegicus) jantan, tikus putih yang digunakan berumur 2 bulan (umur tikus dewasa) dengan rata-rata berat badan yang dapat dilihat pada tabel 2 .

Hewan uji dibuat hiperkolesterolemia dengan

Tabel 1 | Prosedur pemeriksaan kadar kolesterol total darah metode CHOD-PAP

\begin{tabular}{rccc} 
& $\begin{array}{c}\text { Blanko } \\
(\mu \mathrm{L})\end{array}$ & $\begin{array}{c}\text { Standar } \\
(\mu \mathrm{L})\end{array}$ & $\begin{array}{c}\text { Pemeriksaan } \\
(\mu \mathrm{L})\end{array}$ \\
\hline Serum & 0 & 0 & 10 \\
Standar & 0 & 10 & 0 \\
Reagen & 1000 & 1000 & 1000
\end{tabular}

kemudian dilakukan pengambilan darah untuk mengukur kadar kolesterol total sebelum diberikan ekstrak etanol daun ubi jalar ungu (Ipomoea batatas (L.) Lam). Hewan uji pada kelompok perlakuan diberikan ekstrak etanol daun ubi jalar ungu selama 14 hari, kemudian dilakukan pengambilan darah untuk mengukur kadar kolesterol total sesudah pemberian ekstrak etanol daun ubi jalar ungu. Hasil penelitian pemeriksaan kadar kolesterol total tikus putih hiperkolesterolemia sebelum dan sesudah pemberian ekstrak etanol daun ubi jalar ungu dapat dilihat pada tabel 3.

Berdasarkan penelitian yang telah dilakukan diperoleh hasill terjadi penurunan kadar kolesterol total sebelum dan sesudah pemberian ekstrak etanol daun ubi jalar ungu. Hewan uji yang digunakan adalah tikus putih strain wistar (Rattus norvegicus) dengan jumlah sampel 10 ekor tikus putih dibagi menjadi 2 kelompok yaitu 5 kelompok kontrol hiperkolesterolemia dan 5 kelompok perlakuan, menurut World Health Organization (WHO) bahwa hewan coba untuk penelitian minimal 5 ekor tikus per kelompok perlakuan. Tikus yang digunakan yaitu tikus berjenis kelamin jantan, karena yang betina mengalami masa datang bulan dan ini berpengaruh terhadap proses metabolisme yang dikhawatirkan mempengaruhi hasil penelitian [5].

Tikus sampel penelitian ini memiliki berat badan yang beragam. Berat badan tikus dievaluasi mulai

Tabel 2 | Rata-rata berat badan tikus pada penelitian sebelum dan sesudah pemberian ekstrak etanol daun ubi jalar ungu (dosis $\mathbf{2} \mathrm{mg} / \mathrm{kgBB}$ )

\begin{tabular}{rcc} 
Kelompok & $\begin{array}{c}\text { Rata-rata BB } \\
\text { sebelum perlakuan } \\
\text { (gram) }\end{array}$ & $\begin{array}{c}\text { Rata-rata BB } \\
\text { sesudah perlakuan } \\
\text { (gram) }\end{array}$ \\
\hline Kontrol & 170 & 208 \\
Perlakuan & 175 & 203
\end{tabular}

Tabel 3 | Rata-rata kadar kolesterol total tikus hiperkoklesterolemia sebelum dan sesudah pemberian ekstrak etanol daun ubi jalar ungu

\begin{tabular}{rcccc} 
Kelompok & $\begin{array}{c}\text { Pre-test (sebelum } \\
\text { perlakuan) }(\mathrm{mg} / \mathrm{dl})\end{array}$ & $\begin{array}{c}\text { Post-test (sesudah } \\
\text { perlakuan) }(\mathrm{mg} / \mathrm{dl})\end{array}$ & $\begin{array}{c}\text { Selisih pre-test dan } \\
\text { post-test }(\mathrm{mg} / \mathrm{dl})\end{array}$ & $\begin{array}{c}\text { Persentase kadar } \\
\text { kolesterol total }(\%)\end{array}$ \\
\hline $\begin{array}{r}\text { Kontrol } \\
\text { Perlakuan }\end{array}$ & 189,89 & 190,27 & 0,38 & 0,49 \\
\end{tabular}

memberikan pakan lemak sapi selama 7 hari, dari diadaptasi selama 3 hari, selama penelitian 
hingga akhir penelitian. Selama penelitian penimbangan berat badan dilakukan setiap minggu, dengan tujuan untuk menentukan dosis setiap pemberian perlakuannya. Hasil evaluasi penimbangan berat badan dapat dilihat pada tabel 2.

Pakan standar yang terdiri dari air, protein kasar, lemak kasar, serat kasar, abu, kalsium, phosphor, antibiotika, coccidiostat yang telah diolah menjadi bentuk padat berupa $A D$ II serta minum diberikan secara ad libitum yaitu sesuai dengan kecukupan gizi per ekor tikus putih [6].

Pemeriksaan kadar kolesterol total pada penelitian ini menggunakan serum sebagai sampel. Metode yang digunakan dalam percobaan adalah CHOD-PAP yaitu salah satu cara penzimatik. Kelebihan pemeriksaan dengan metode ini adalah hasil yang diperoleh lebih teliti dan akurat, karena dapat pengukur kadar lebih tinggi dan rendah. Prinsip CHOD-PAP adalah kolesterol oksidase akan menghasilkan peroksida, peroksida yang terbentuk diwarnai dengan 4 amino ampitirin membentuk quinoneimine yang berwarna merah muda. Absorbansi warna ini sebanding dengan kolesterol dalam sampel [7]

Serum diperoleh dari darah tikus putih yang sebelumnya berpuasa terlebih dahulu. Hal ini dilakukan agar tidak terjadi kesalahan pengukuran akibat adanya pengaruh dari lemak yang baru dikonsumsi. Darah yang digunakan berasal dari bagian vena sinus orbital di bagian sudut mata. Vena sinus orbital dipilih karena pengambilan darah pada bagian vena orbital lebih mudah, dan meminimalisir kemungkinan darah lisis saat pengambilan darah, pengambilan darah pada vena orbital sering dilakukan untuk penelitian dengan desain pre-test and post-test. Apabila sel darah merah lisis maka serum akan menjadi berwarna dan warna tersebut dapat ikut terserap panjang gelombangnya dan kadar yang diperoleh menjadi besar atau tidak sesuai.

Hewan uji tikus putih kelompok perlakuan diberi ekstrak etanol daun ubi jalar ungu dengan dosis $2 \mathrm{mg} / \mathrm{kgBB} / \mathrm{hari}$. Pembuatan ekstrak etanol daun ubi jalar ungu dilakukan di Laboratorium Biologi Farmasi Universitas Gadjah Mada Yogyakarta. Proses awal pembuatan ekstrak etanol daun ubi jalar ungu terlebih dahulu dibuat simplisia kering (penyerbukan) hingga mencapai derajat kehalusan tertentu. Proses simplisia dapat mempengaruhi mutu ekstrak dengan beberapa hal yaitu semakin halus serbuk simplisia maka proses ekstraksi makin efektif sehingga tingkat homogenitas dan kelarutan daun ubi jalar ungu lebih banyak terambil [8].

Metode penyaringan yang digunakan dalam penelitian ini adalah metode maserasi. Metode maserasi merupakan ekstraksi dengan pelarut cara dingin, tidak memerlukan pemanasan yang dapat merusak zat aktif dalam daun ubi jalar ungu khususnya quercetin. Proses maserasi menggunakan pelarut etanol $70 \%$. Pengadukan pada proses maserasi dilakukan kurang lebih selama 3 jam kemudian didiamkan selama 24 jam untuk memberikan kesempatan zat aktif yang tersari di dalam sel untuk berdifusi keluar sel. Penggunaan etanol sebagai pelarut diharapkan dapat melarutkan senyawa flavonoid khususnya quercetin. Selain itu etanol juga bersifat universal sehingga dapat menarik sebagian besar senyawa kimia yang terkandung di dalam simplisia (polar dan non polar). Filtrat yang diperoleh dengan penyaringan menggunakan kain kasa.Ekstrak kental kemudian diuapkan di waterbath pada suhu 70\% dengan bantuan kipas angin. Ekstrak yang diperoleh ditimbang. Hasil ekstrak etanol daun ubi jalar ungu sebanyak $30 \mathrm{gr}$ [9].

Hasil dari penetapan kadar rata-rata quercetin dalam ekstrak didapatkan 14,08 mg/100gram ekstrak etanol daun ubi jalar ungu. Penetapan quercetin bertujuan untuk menentukan dosis yang akan diberikan kepada tikus putih. Penentuan dosis untuk perlakuan pada tikus putih wistar berdasarkan ketetapan kadar quercetin yaitu sebesar $2 \mathrm{mg} / \mathrm{kgBB} /$ hari, sehingga dihitung dengan menggunakan rumus:

$$
\frac{2 \mathrm{mg}}{0,1408} \times \frac{B B \text { tikus }(\mathrm{gram})}{1000}
$$

Kadar kolesterol serum yang tinggi merupakan faktor utama terjadinya asterosklerosis yang dapat mengakibatkan berbagai penyakit kardiovaskular seperti penyakit jantung koroner dan stroke. Penyebabnya tidak lain adalah plak yang terbentuk oleh kolesterol dalam darah yang akan menyumbat 
saluran pembuluh darah. Akibatnya sebagian fungsi organ bila terjadi penyumbatan akan terhenti atau tidak berfungsi sebagaimana mestinya.Daun ubi jalar ungu yang mengandung berbagai macam zat yang dapat menurunkan kadar kolesterol total darah. Flavonoid yang terkandung dalam daun ubi jalar ungu terkhususnya quercetin dapat menurunkan kadar kolesterol darah dengan cara meningkatkan ekskresi asam empedu [10].

Peningkatan kadar kolesterol total dikarenakan induksi lemak sapi selama 7 hari. Selama penginduksian, senyawa yang terkandung di dalam lemak sapi seperti kolesterol dan asam lemak jenuh yang tinggi terkandung dalam lemak sapi dapat menyebabkan gangguan terhadap metabolisme kolesterol tubuh tikus putih yang ditandai dengan peningkatan nilai kolesterol total tikus putih.

Berdasarkan penelitian yang telah dilakukan, didapatkan hasil kadar kolesterol total mengalami penurunan sesudah pemberian ekstrak etanol daun ubi jalar ungu. Hasil penelitian ini juga mendukung hasil penelitian [11] yang menunjukkan bahwa ekstrak etanol daun ubi jalar ungu dengan pemberian dosis quercetin 2 $\mathrm{mg} / \mathrm{kgBB} /$ hari dapat menurunkan konsentrasi serum kolesterol total. Mekanisme kerja quercetin, yaitu dapat menurunkan kadar kolesterol total dan kadar kolesterol LDL dengan cara menghambat sekresi Apo-B 100 pada sel CACO2 serta dapat menurunkan aktivitas MTP yang berperan pada pembentukan lipoprotein dengan mengkatalisa perpindahan lipid ke molekul Apo-B. Quercetin juga dapat menghambat aktivitas enzim HMG-KoA reduktase, yaitu enzim yang berperan dalam pembentukan kolesterol. Sifat quercetin sebagai antioksidan dapat mencegah oksidasi LDL dengan mengikat radikal bebas dan transisi ion logam dalam menghambat peroksidasi lipid. Perokdiasi lipid adalah proses perubahan asam lemak melalui abstraksi hydrogen. Peroksidasi lipid dapat menimbulkan kerusakan seperti penyakit jantung (Siregar, 2015). Berdasarkan sebuah penelitian oleh [12] terhadap tikus yang diberi etanol untuk merusak hatinya, quercetin berhasil menurunkan kolesterol total yang teroksidasi dan menaikkan jumlah glutathione, sehingga dapat berfungsi untuk melindungi hepar. Quercetin juga tidak dapat bekerja sendiri sebagai antioksidan, untuk dapat menjalankan fungsinya sebagai antioksidan, quercetin dibantu dengan senyawasenyawa lain yang terkandung di dalam daun ubi jalar ungu [13].

\section{Kesimpulan}

Penurunan kadar kolesterol total pada tikus hiperkolesterolemia sesudah pemberian ekstrak etanol daun ubi jalar ungu dosis $2 \mathrm{mg} / \mathrm{kgBB} / \mathrm{hari}$ sebesar $30,52 \%$

\section{Apresiasi}

Peneliti mengucapkan terima kasih kepada RISTEK DIKTI atas dana yang telah diberikan untuk penelitian ini

\section{Bibliografi}

1. Setyawati, 2014, Bakar Lemak Tanpa Lemas Tanpa Lapar, Araska, Yogyakarta

2. Rohan, Suprapto, 2014, Patologi \&Patofisiologi Penyakit, Cetakan Pertama, Nuha medika, Yogyakarta.

3. Richana, 2013, Menggali Potensi Ubi Kayu \& Ubi Jalar, Nuansa Cendana, Bandung

4. Sulastri, Erlidawati, Syahrial, Nazar M., Andayani T., . 2013. Aktivitas Antioksidan Ekstrak Etanol Daun Ubi Jalar Ungu (Ipomea batatas L.) Hasil Budidaya Daerah Saree Aceh Besar. Jurnal Rekayasa Kimia dan Lingkungan Vol. 9, hal $125-130$.

5. Prasetya, 2012, Peluang Jitu Berternak Tikus, Cetakan Pertama, Pustaka Baru Press, Yogyakarta.

6. Ngatidjan, 2006, Metode Laboratorium dalam Toksikologi, Bagian Farmakologi dan Toksikologi Fakultas Kedokteran Universitas Gadjah Mada, Yogyakarta, hal : 67-68.

7. Kementrian Kesehatan RI, 2010, Pedoman Pemeriksaan Kimia Klinik, Jakarta

8. Departemen Kesehatan RI, 2000, Parameter Standar Umum Ekstrak Tumbuhan Obat, Cetakan Pertama, Jakarta, hal 10

9. Salamah N., Widyasari E., 2015, Aktivitas Antioksidan Ekstrak Metanol daun kelengkeng (Euphoria longan (L) Steud.) dengan Metode Penangkapan Radikal 2,2'Difenil-1-Pikrilhidrazil, Jurnal Pharmaciana, Vol. 5, hal 25-34.

10. Witosari N., Widyastuti N., 2009.? atau 2014? Pengaruh Pemberian Jus Daun Ubi Jalar (Ipomoea batatas (L). Lam) Terhadap Kadar Kolesterol Total Tikus Wistar Jantan (Rattus norvegicus) yang Diberi 
Pakan Tinggi Lemak. Journal of Nutrition College, volume 3, hal 638-646.

11. Sudiarto, Setyawati S.K., dan Shinta F.N., 2010.The Effect of Quercetin on Adipocyte-Fatty Acid Binding Protein Level.Jurnal Kedokteran Brawijaya,Vol. 26, hal 24-27

12. Boyer J., Liu R.H., 2004, Apple Phytochemical and Their Health Benefits. Nutrition Journal. Vol 3, hal 1-15

13. Siregar I.N.R., 2015, The Effect Of Eugenia Polyantha Extract On LDL Cholesterol. J MAJORITY.Volume 4, hal $85-92$ 